\title{
Growth and litter decomposition of woody species inoculated with rhizobia and arbuscular mycorrhizal fungi in Semiarid Brazil
}

\author{
Maria Rita SCOTTI*, Eduardo José A. CORRÊA \\ Departamento de Botânica, Instituto de Ciências Biológicas, Universidade Federal de Minas Gerais, Avenida Antonio Carlos, 6627, Pampulha, \\ Cep: 31.270-901 Belo Horizonte Minas Gerais, Brazil
}

(Received 28 May 2002; accepted 28 April 2003)

\begin{abstract}
Jaíba Project is an irrigation enterprise and its forest reserve is one of the largest protected areas of dry deciduous forest of Caatinga. However, two accidental fires burned about $90 \%$ of the area, resulting on the elimination of the trees. This study intended to evaluate the effects of dual inoculation with Rhizobium and mycorrhizal fungi on growth of Anadenanthera peregrina and its contribution to intercropped native species (Myracrodruon urundeuva Fr. Allem., Schinopsis brasiliensis Engl. and Acacia sp.) and to increase the soil nutrients through litter decomposition as a strategy for the restoration of the reserve. The plants of Anadenanthera peregrina which were inoculated with rhizobia strain BHICB-A10 and associated with AM, showed a significant increase in height and total nitrogen content over that uninoculated plants. In plots where A. peregrina was inoculated, growth and survival of intercropped plants as Myracrodruon urundeuva, were favoured. This result may be explained by the faster decomposition rate of $M$. urundeuva litter and by the increase of soil nutrients which was related with its lowest lignocellulous content. The mixture of A. peregrina with M. urundeuva was the best model for restoration.
\end{abstract}

bradyrhizobia / mycorrhizal fungi / Anadenanthera peregrina / semiarid / Caatinga

Résumé - Croissance et décomposition de la litière d'espèces ligneuses inoculées avec des rhizobia et des champignons mycorhiziens à arbuscules dans le Brésil semi-aride. Dans la réserve de forêt sèche de Caatinga, zone d'application du Projet Jaíba pour le développement socio-économique de cette région semi-aride du Brésil, deux feux accidentels ont brûlé environ $90 \%$ des arbres. La stratégie de restauration de la réserve réside dans la possibilité d'augmenter l'apport d'éléments minéraux au sol par l'installation de cultures mixtes d'espèces ligneuses fixatrices et non fixatrices. L'étude a eu pout but d'évaluer les effets de la double inoculation de Anadenanthera peregrina par des souches de Bradyrhizobium et de champignon mycorhizien à arbuscules sur la croissance de cet arbre et de celle des autres espèces associées natives de cette région (Myracrodruon urundeuva Fr. Allem., Schinopsis brasiliensis Engl. et l'Acacia sp.). Les effets possibles de cette inoculation sur la capacité des arbres à augmenter la disponibilité des éléments minéraux du sol provenant de la décomposition des litières de ces arbres pourraient aider à la restauration de la réserve. La double inoculation entraîne une augmentation significative de la hauteur d'Anadenanthera peregrina et des autres espèces associées ainsi que leur teneur en azote et leur taux de survie, particulièrement en ce qui concerne $M$. urundeuva. Le taux de décomposition plus rapide des feuilles de $M$. urundeuva pourrait être attribué à un plus faible contenu ligno-cellulosique. L'association de A. peregrina avec M. urundeuva représente le meilleur modèle à utiliser dans les problèmes de restauration des sols.

bradyrhizobia / champignon mycorhizien à arbuscules / Anadenanthera peregrina / semi-aride / Caatinga

\section{INTRODUCTION}

Brazil's semi-arid lands comprise an area of 980711 sq. $\mathrm{km}$, distributed throughout 8 states of the Northeast and the north of Minas Gerais. Inserted in semiarid of Minas Gerais State, Jaíba Project is an irrigation enterprise, established for the improvement of agricultural production and for the economic and social growth of the region. Climate and vegetation are between the woody Caatinga or "Dry Deciduous Forest" and Cerrados (Brazilian edaphic savannas) and such vegetation is also called "Woody Caatinga" [36] showing as dominant botanical families: Mimosaceae, Caesalpiniaceae, Fabaceae and Bignoniaceae [12]. In 1993 two accidental burns reached about $90 \%$ of the ecological reserve, which was seriously affected with the elimination of trees. Fire may promote soil degradation depending on the regeneration capacity of the ecosystem. The burned area of forest reserve has been invaded by species of low load trees and shrub mesh, called "Carrasco vegetation" which has restrained the sprouting of woody species. Thus, a very slow rate of regeneration of valuable tropical species of "Woody Caatinga" has been observed [45] such as Myracrodruon urundeuva $\mathrm{Fr}$. Allem. (Anacardiaceae) that is a species threatened with extinction [8]. Therefore, the recovery of the burned Reserve should have priority. A nurse plant phenomenon, wherein one plant facilitates establishment of another, has been described in arid and semiarid regions throughout the

* Corresponding author: scottimuzzi@ig.com.br 
world [10]. The most commonly mechanism of facilitation involves woody plants [16] such as leguminous trees that are more efficient than non-leguminous in maintaining $\mathrm{N}$ and $\mathrm{P}$ availability [30] due to their ability to develop symbiotic associations with both rhizobial bacteria and arbuscular mycorrhizal fungi (AMF). Bacteria of the genus Rhizobium or Bradyrhizobium, capable of fixing the atmospheric nitrogen in root nodules, can guarantee nitrogen supply to the leguminous tree, making it independent of the nitrogen in the soil. The access of the roots to the nutrients, especially phosphate, can be enhanced by the association with mycorrhizal fungi (AMF). Literature has been confirming that dual inoculation significantly increases not only dry weight, nitrogen and phosphorus content of the shoot, but also the height and diameter of trunk and reduces plant mortality index [4, 15, 20, 26-28, 38]. This way such increase of the $\mathrm{N}$ and $\mathrm{P}$ concentration in the leaves increases the litter quality and improves the turnover and decomposition of the biomass which adds nutrients to soil and produces the soil organic matter (SOM). One of the most significant impacts after burning is the loss of soil structure as evidenced by a unbalance in soil porosity due the loss of organic matter (SOM). SOM stabilizes soil aggregates and the porosity, increases the water holding capacity of soils, influences the soil fertility and serves as a nutrient sources for soil decomposers [42]. The rate of plant decomposition depends on the soil chemical composition and many studies have demonstrated the importance of carbon:nitrogen ratios in determining decomposition rates [9], as well as the importance of ligno-cellulose index [6], polyphenols [31, 46] and tannin [32] contents in retarding decomposition. In view of these observations we have proposed the revegetation of an experimental burned area of forest reserve with Anadenanthera peregrina (L.) Spegazzini, a native leguminous tree belonging to Mimosoideae, so called "angico", inoculated with Bradyrhizobium sp. and arbuscular mycorrhizal fungi (AMF). The experimental area was cultivated with A. peregrina intercropped with Anacardiaceae species: Schinopsis brasiliensis Engl. (aroeira) and Myracrodruon urundeuva Fr. Allem. (brauna) in blocks 1 and 2 respectively, and with a leguminous species Acacia sp. (acacia) in block 3 that are also native species of Caatinga. The purpose of the present study was to determine: (i) the effects of dual inoculation with Rhizobium and mycorrhizal fungi on growth and nitrogen content of $A$. peregrina, (ii) the growth of the other native species in mixed plantation with $A$. peregrina, and (iii) the dynamic of litter decomposition, nutrient release and change of soil nutrient, as a strategy for the reestablishment of plant species and restoration of semi-arid ecosystems.

\section{MATERIALS AND METHODS}

\subsection{Study site}

The study area is located in the Forest Reserve (Woody Caatinga), in the north of Minas Gerais State in Brazil. It is an area included in semiarid ( $15^{\circ} 09^{\prime} 03^{\prime}$ 'S $\left.43^{\circ} 49^{\prime} 26^{\prime \prime} \mathrm{W}\right)$ characterized by annual pluviometric rates of $800 \mathrm{~mm}$ concentrated in the spring-summer months from November to January and about 10 dry months. Mean annual rainfall in $1997 / 1999$ was $238.9 \mathrm{~mm}$ in the summer (December to February) and in dry season (July to October) a water deficit of $35 \mathrm{~mm}$ occurred. The evapo-transpiration potential (EP) is very high with a relatively low humidity of $12 \%$, according to a report by consultants
[12]. The Forest Reserve has 7500 hectares and it is one of the largest protected areas of "woody Caatinga", the proeminent vegetation composed by xerophytic trees and shrubs with a total density of 1029.28 trees per hectare. The arboreal stratum showed height of 10 to $25 \mathrm{~m} \mathrm{[36].} \mathrm{In} 1993$ two spots of fire reached about $90 \%$ of the area, of which $66.6 \%$ was seriously affected with the elimination of trees, and the area was invaded by a dense community of interlaced shrubs, coriaceous leaves and never larger than 2 to $5 \mathrm{~m}$ [36] characteristics of Carrasco. Predominant soil types are alic yellow podsols with high infiltration rate and low levels of organic matter [12]. The mean temperature in a year is $26-29^{\circ} \mathrm{C}$. An area of 1.08 hectare was cleared of Carrasco plants and prepared for Anadenanthera peregrina cultivation intercropped with Myracrodruon urundeuva Fr. Allem., Schinopsis brasiliensis Engl. and Acacia sp.

\subsection{Soil samples}

The samples were collected from the top $20 \mathrm{~cm}$ of 10 spots/ block in a transect of $100 \mathrm{~m}$ across each of 3 blocks and mixed for each block, 4 and 24 months after transplanting. Similar transect was made in 3 adjacent fields with "Carrasco vegetation", Caatinga reserve and in a burned area without woody vegetation (disturbed site) where soil samples were collected. The samples were analyzed for chemical and physical properties. The soil analysis was made by Brazilian company of agricultural research [14]. The texture of the soil was identified as sandy loam with the textural composition as follows: block 1coarse sand $=55 \%$, fine sand $=30 \%$, silt: $4.0 \%$, clay $=11 \%$; block 2 coarse sand $=57.0 \%$, fine sand $=27.0 \%$, silt $=3 \%$, clay $=13 \%$; and block 3 - coarse sand $=56.0 \%$, fine sand $=28 \%$, silt $=4 \%$, clay $=12 \%$ and chemical analysis is showed in Table III.

\subsection{Selection of inoculum and culture conditions}

Rhizobial strains (BHICB) used belonging to the collection of the Federal University of Minas Gerais (UFMG) and were isolated from Anadenanthera peregrina (L.) nodules collected from other parts of the country. These strains were previously screened to the appropriate rhizobia interactions with $A$. peregrina under greenhouse conditions. Three rhizobia strains (BHICB-A 10, BHICB-A 41, and BHICB-A 90) were selected basing in the high growth promoting effect (data not shown). The bacterial inocula were provided at $1 \mathrm{~mL} \operatorname{perpot}\left(10^{8} \mathrm{cfu} / \mathrm{mL}\right)$, according to Somasegaran and Hoben [43]. Mycorrhizal fungi used were Gigaspora margarita, Scutellospora heterogama and Glomus etunicatum, from our laboratory collection of Federal University of Minas Gerais. Endomycorrhizal inoculation was accomplished by placing into each pot, $1 \mathrm{~mL}$ of suspension composed by 50 spores per species and 150 spores/mL in total of 3 species (Gigaspora margarita, Scutellospora heterogama and Glomus etunicatum ). Previous data (data not presented) indicate the presence of a native mycorrhizal population of Glomus sp. which can potentially set a competition with the inoculant during the root infection and reduce the inoculation effectiveness. Therefore, the use of three selected mycorrhizal species can assure the success of inoculation.

\subsection{Field experiment and treatments}

Seeds of Anadenanthera peregrina ("angico") were briefly dipped in $95 \%$ ethanol, washed six times in sterile water and germinated in humid chamber at $29^{\circ} \mathrm{C}$. Seedlings about $10 \mathrm{~cm}$ high were transplanted into plastic pots of 5 kilograms, filled with soil collected from burned reserve in Jaiba Project. The following treatments were used for each group of 120 plants of A. peregrina: (I) Control: complete fertilization; (triple superphosphate: $500 \mathrm{~kg} \mathrm{ha}^{-1}$; KCl: $382 \mathrm{~kg} \mathrm{ha}^{-1}$; $\mathrm{MgSO}_{4} 7 \mathrm{H}_{2} \mathrm{O}: 50 \mathrm{~kg} \mathrm{ha}^{-1} ; \mathrm{ZnSO}_{4} 7 \mathrm{H}_{2} \mathrm{O}: 46.8 \mathrm{~kg} \mathrm{ha}^{-1} ; \mathrm{Mo}_{7} \mathrm{O}_{24} \mathrm{H}_{2} \mathrm{O}$ : $1.76 \mathrm{~kg} \mathrm{ha}^{-1}$; urea: $222 \mathrm{~kg} \mathrm{ha}^{-1}$ ) according to Somasegaran and Hoben 
Table I. ANOVA for height of Anadenanthera peregrina plants as affected by treatments and blocks at 4, 8, 12 and 20 months after field transplanting.

\begin{tabular}{|c|c|c|c|c|c|c|c|c|c|}
\hline \multirow{3}{*}{ Sources of variation } & \multirow{3}{*}{ d.f } & \multicolumn{7}{|c|}{ Time (months) } & \\
\hline & & \multicolumn{2}{|c|}{4} & \multicolumn{2}{|c|}{8} & \multicolumn{2}{|c|}{12} & \multicolumn{2}{|c|}{20} \\
\hline & & MS & $\mathrm{F}$ & MS & $\mathrm{F}$ & MS & $\mathrm{F}$ & MS & $\mathrm{F}$ \\
\hline Treatment & 4 & 132.36 & $2.16^{\mathrm{NS}}$ & 133.70 & $3.43^{*}$ & 221.44 & $0.47^{\mathrm{NS}}$ & 266.917 & $3.68^{* *}$ \\
\hline Block & 2 & 900.77 & $14.69^{* * *}$ & 1071.58 & $27.53^{* * *}$ & 6357.64 & $13.45^{* * *}$ & 569.407 & $7.85^{* * *}$ \\
\hline Treatment $\times$ Block & 8 & 82.26 & $1.34^{\mathrm{NS}}$ & 78.133 & $2.01^{\mathrm{NS}}$ & 837.943 & $1.77^{\mathrm{NS}}$ & 429.67 & $0.59^{\mathrm{NS}}$ \\
\hline Error & 60 & 61.3 & & 38.927 & & 472.820 & & 725.22 & \\
\hline Total & 74 & & & & & & & & \\
\hline
\end{tabular}

* Significant at $5 \%, * *$ significant at $1 \%, * * *$ significant at $0.1 \%$, NS: not significant difference.

[42, 47]; (II) Control plus arbuscular mycorrhizal fungi (AMF); (III) Fertilization without nitrogen plus inoculation with rhizobia strain BHICB-A10; (IV) Fertilization without nitrogen plus inoculation with rhizobia strain BHICB-A41 plus arbuscular mycorrhizal (AM) fungi; (V) Fertilization without nitrogen plus inoculation with rhizobia strain BHICB-A90 and arbuscular mycorrhizal (AM) fungi. Each group of 120 plants of Myracrodruon urundeuva, Schinopsis brasiliensis and Acacia sp. received complete fertilization. Plants were kept in nursery conditions during 4 months before field transplantation.

\subsection{Experimental design and sampling procedure}

The experiment was set up in a burned area of the Reserve. The field experimental design was a completely randomized blocks with three blocks $\left(3600 \mathrm{~m}^{2}\right.$ each) and five treatments. Five plots $(24 \times$ $30 \mathrm{~m}$ ), corresponding to each treatment, were distributed in an aleatory way in each block. Each plot received 40 plants of A. peregrina and 40 plants of one of the native species with a spacing of $3 \times 3 \mathrm{~m}$. In the block I A. peregrina plants were cultivated with Myracrodruon urundeuva Fr. Allem., in the block II with Schinopsis brasiliensis Engl. and Acacia sp. was the intercropped plants in the block III. Four monthold seedlings were transplanted in the field during the rainy season. To ensure the survival of the seedlings, irrigation with truck were provide during the dry season of the first year $(10 \mathrm{~L} /$ plant/week). Six plants of A. peregrina from each treatment were harvested 4,8 , and 12 months after transplantation and the leaves were dried to constant weight at $60{ }^{\circ} \mathrm{C}$ and digested for the determination of total nitrogen by Nessler's Reagent Method [33] and phosphorus analysis was done using the Vanado-Molybdate Method [40]. The roots of the collected plants were carefully dug up and the finer ones picked and clarified. All the infected and uninfected root segments were selected randomly, and mycorrhizal infection assessed by the gridline intersect method [18]. Data were subjected to analysis of variance (ANOVA) and means separated by Tuckey multiple-range test. The height of all $A$. peregrina plants were recorded at 2,8,12 and 20 months after transplantation while the height of intercropped plants were analysed only at 20 months.

\subsection{Litter sampling}

Leaves of adult plants which had recently fallen over the ground in August/October were collected. Leaf litter was air dried to a constant weight at room temperature, cut and enclosed ( $13 \mathrm{~g}$ per bag) in $20 \mathrm{~cm} \times$ $20 \mathrm{~cm}$ nylon bags made with $1 \mathrm{~mm}$ mesh net. Five sub-samples of each litter type were retained for initial moisture and chemical analyses.

\subsection{Experimental design}

The field experimental design was a completely randomized block $5 \times 2 \times 3$ with 15 replicates. Fifteen bags of each litter type or treatment (1- A. peregrina, 2- M. urundeuva, 3- S. brasiliensis, 4- A. peregrina $+M$. urundeuva, 5- A. peregrina $+S$. brasiliensis), of each time of analysis ( 4 and 8 months) were laid at the bottom of a hole ( $5 \mathrm{~cm}$ deep) in each of the 3 blocks $(50 \mathrm{~m} \times 50 \mathrm{~m})$, where A. peregrina and intercropped species were cultivated, with a total of 450 bags. In each block the bags were incubated in plots where $A$. peregrina plants were inoculated with the rhizobia strain BHICB-A10 and AMF. In each sampling date fifteen bags of each litter type were retrieved for analyses. In the laboratory the leaf litter were removed from the bags, cleaned and weighed before (fresh weight) and after drying at $60^{\circ} \mathrm{C}$ and $80^{\circ} \mathrm{C}$ for $48 \mathrm{~h}$. Corrections for inorganic contaminants were made after determining ash $\left(4 \mathrm{~h}, 600{ }^{\circ} \mathrm{C}\right)$.

\subsection{Decomposition rates and chemical composition analysis}

Weight loss data was estimated [48] using the following equation: $\% \mathrm{RM}=\left(\mathrm{W}_{0}-\mathrm{W}_{\mathrm{t}} / \mathrm{W}_{0}\right) \times 100$, where $\mathrm{W}_{0}$ is the initial litter dry weight and $\mathrm{W}_{\mathrm{t}}$ is the dry weight of the remaining mass $(\mathrm{RM})$ litter in the bag when collected. The decay rate $\left(K\right.$ year $\left.^{-1}\right)$ which estimates litter disappearence on an yearly basis and that is proportional to actual decomposition rates, was calculated using the negative exponential decay function [34]: $\mathrm{W}_{\mathrm{t}}=\mathrm{W}_{0} e^{-\mathrm{kt}}$. Chemical determination of the residue, including soluble components, hemicellulose, cellulose and lignin were made by the acid detergent fiber method [19] and the analysis of nitrogen by Nessler's Reagent method [33] and Phosphorus by vanado-molybdate method as described by Sarruge and Haag [40] .

\section{RESULTS AND DISCUSSION}

Inoculation with BHICB-A10 plus mycorrhizal fungi produced significant differences in height growth of $A$. peregrina only 20 months after transplanting (Fig. 1, Tab. I). Before that time the plants did not show difference in height and this cannot be attributed to the interaction between block and treatment (Tab. I). The non significant differences of $A$. peregrina heights until the twelfth month (Tab. I) appear to be related to the slow growth rate of native species under dry season (Fig. 1). The treatment of BHICB-A10 plus mycorrhizal fungi was the best (Fig. 1), allowing the plants to reach an average height of $1.95 \mathrm{~m}$. These results are similar to those described for Acacia pennatula 


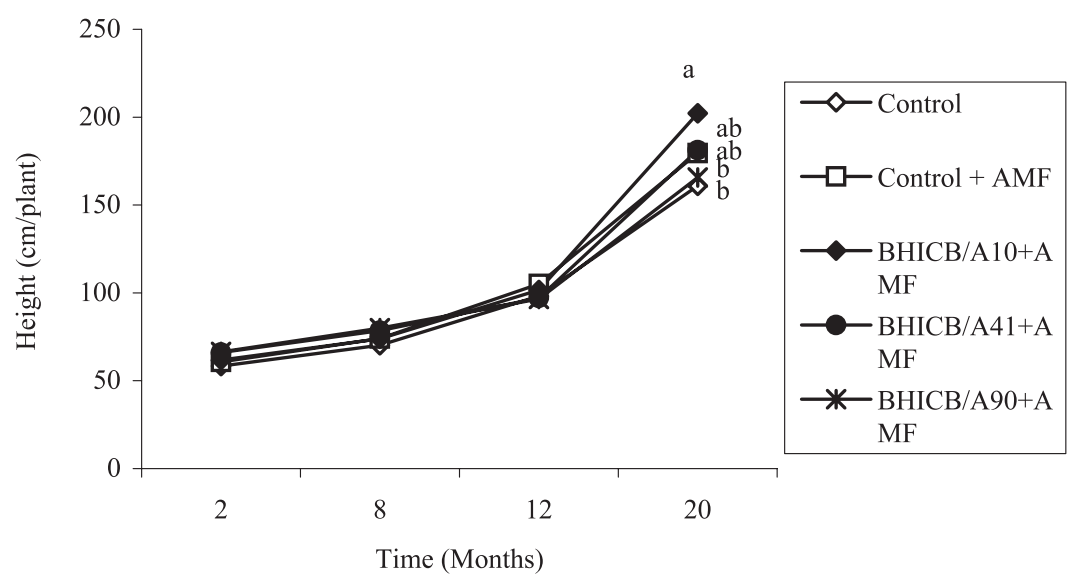

Figure 1. Height (A) of Anadenanthera peregrina (L) plants inoculated with rhizobia strains (BHICB) and mycorrhizal fungi (AMF). Means with different letters are significantly different as determined by Tuckey multiple-range test at the $5 \%$ confidence level $(P \leq 0.05)$. NS: not significantly different.
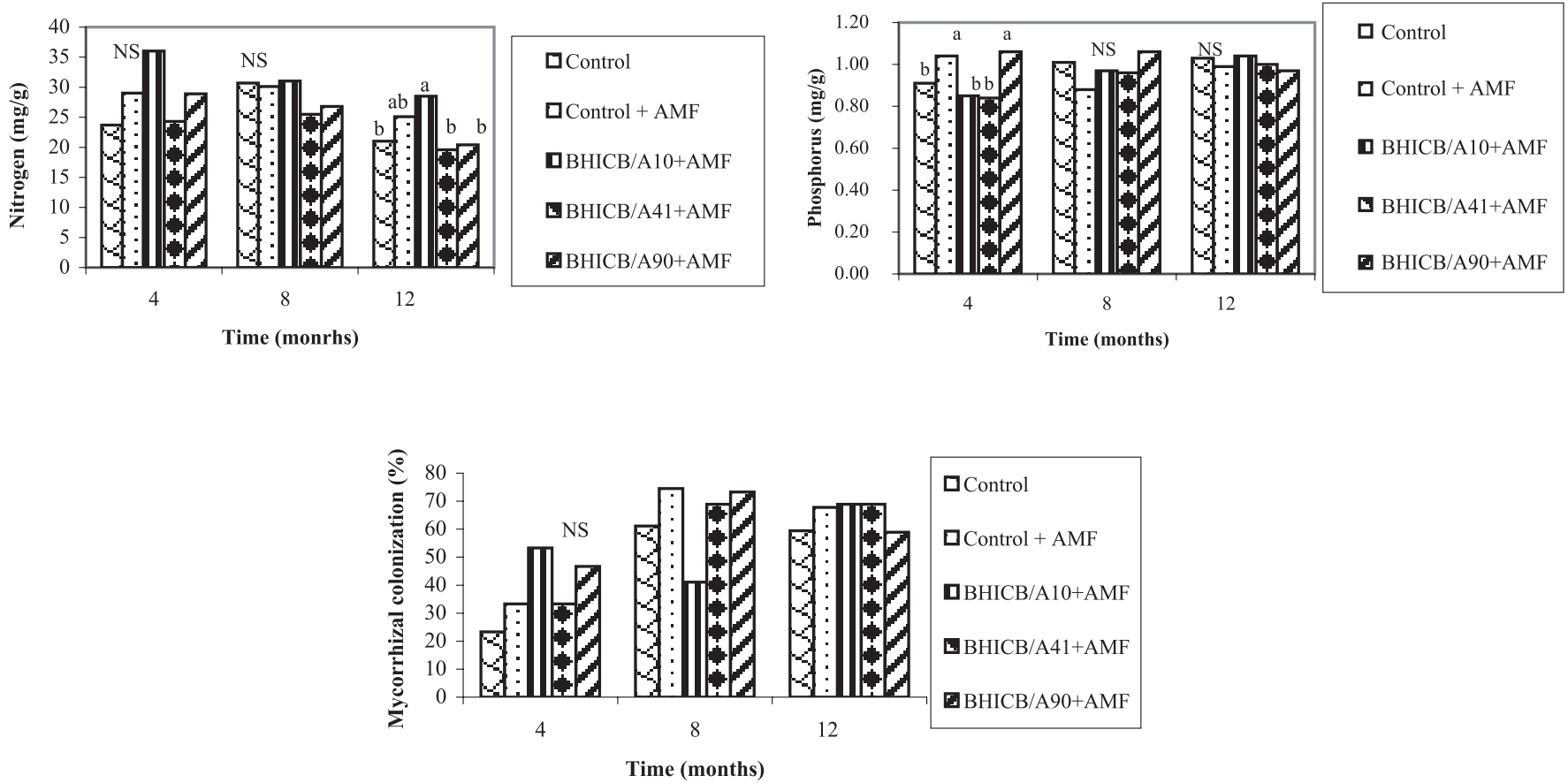

Figure 2. Nitrogen and phosphorus contents of leaves (dry matter) and root colonization of Anadenanthera peregrina plants inoculated with rhizobia (BHICB) and mycorrhizal fungi (AMF) 4,8 and 12 months after field transplanting. Means with different letters are significantly different as determined by Tuckey multiple-range test at the 5\% confidence level $(P \leq 0.05)$. NS: not significantly different.

which reached $2 \mathrm{~m}$ of height in the first year of cultivation at two sites in Mexico [38]. In the twelfth month of cultivation, the plants co-inoculated with AMF and BHICB-A10 presented a higher in the height growth and in content of nitrogen in dry matter than those inoculated with the other rhizobia strains. Since nitrogen content of BHICB-A10 plus mycorrhizal fungi inoculated was higher than fertilized plants, the strain BHICBA10 appears to be an efficient nitrogen fixer (Fig. 2). This inoculation resulted in a significant improvement in nitrogen content corresponding to $2.8 \mathrm{~g} \mathrm{~N} /$ plant based on the mean of total dry weight per plant (108.0 g/plant). These data were compatible with those observed with Acacia nilotica (2.2 g N/plant) during the first year of planting in semi-arid land [24]. The presence of mycorrhizal fungi (AMF) in the roots may improve the access of the roots to the nutrients, especially phosphate [25]. The fungi develop a mycelium on the surface of the roots that allows plants to increase the absorption of water and nutrients. As shown in Figure 2, AMF inoculation enhanced phosphorus content of fertilized plants only in the fourth month of cultivation.

After that time, neither phosphorus content nor root colonization (Fig. 2) were significantly different among treatments. This result may be attributed to a greater availability of soil nutrients promoted by rainy season [28] and consequently the reduction of AMF root colonization. Despite the low native AMF population found in previous studies ( 1.77 spores/g soil) the roots of uninoculated plants were well colonized suggesting higher infective ability of native AMF species, in spite of its 

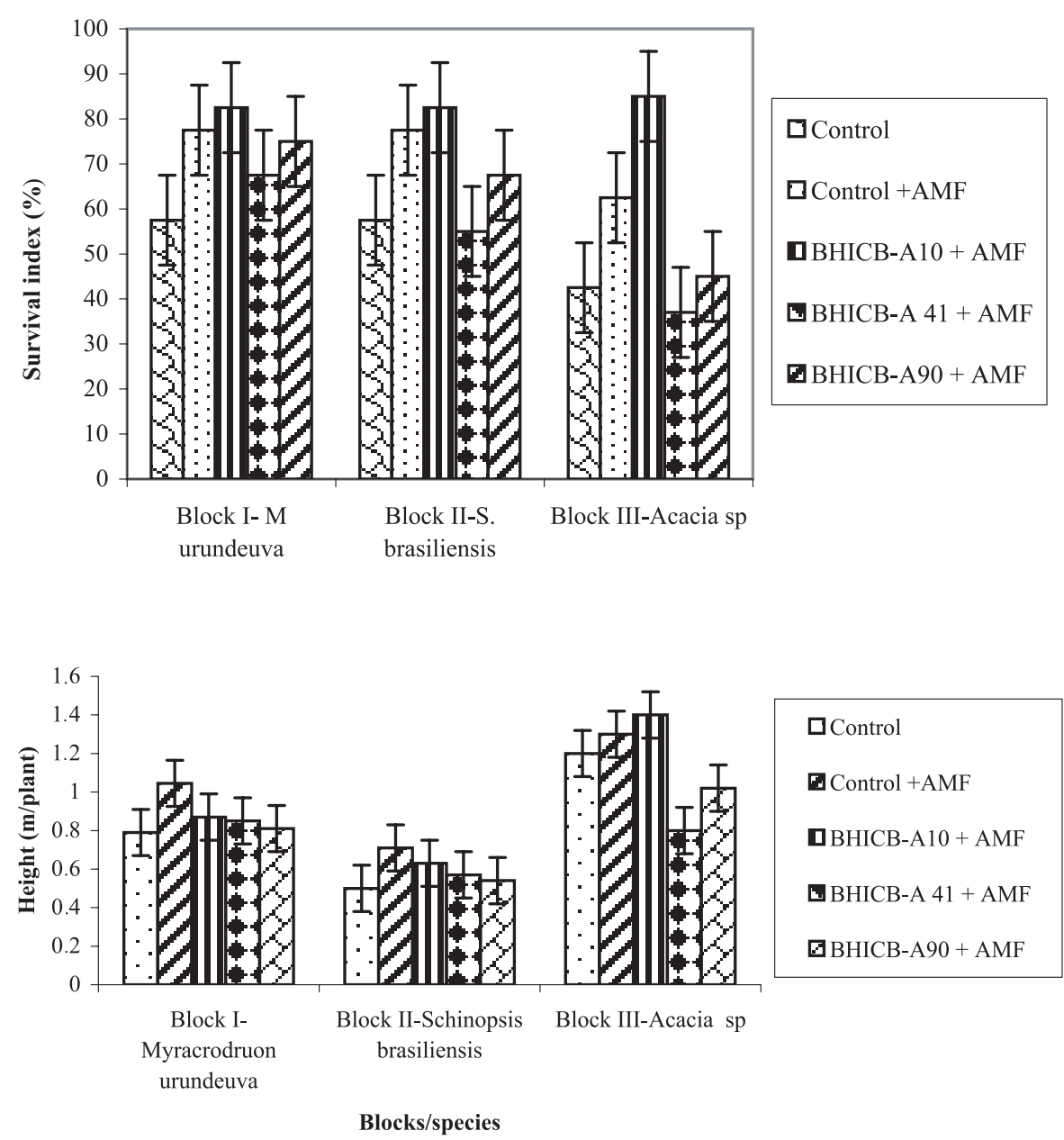

Table II. ANOVA for height of Anadenanthera peregrina as affected by each block.

\begin{tabular}{lcccc}
\hline & \multicolumn{4}{c}{ Time (months) } \\
\cline { 2 - 5 } & 4 & 8 & 12 & 20 \\
\hline Block I & $60.04^{\mathrm{b}}$ & $83.2^{\mathrm{a}}$ & $149^{\mathrm{a}}$ & $195^{\mathrm{a}}$ \\
Block II & $71.2^{\mathrm{a}}$ & $73.4^{\mathrm{b}}$ & $147^{\mathrm{a}}$ & $177^{\mathrm{b}}$ \\
Block III & $62^{\mathrm{b}}$ & $70.8^{\mathrm{b}}$ & $124^{\mathrm{b}}$ & $166^{\mathrm{b}}$ \\
\hline
\end{tabular}

Means with different letters on each column are significantly different as determined by Tuckey multiple-range test at the 5\% confidence level $(P \leq$ $0.05)$.

inability to provide a significant contribution for the plant's growth (Fig. 1). Therefore, the infection rate, done by mycorrhizal colonization, could not be correlated to its effectiveness (Fig. 2). As we have observed and according to literature [3, 37] the extent of root colonization is not an indication of AMF's ability to enhance plant growth. AM fungi can benefit the plants in different ways, not only improving phosphorus and mineral nutrition $[26,41]$ but also enhancing absorption of the water during drought conditions $[2,11]$. This possibility may be reinforced by the results shown in Figure 3 which indicate that AMF inoc-

\section{口Control}

口Control +AMF

DBHICB-A10 + AMF

- BHICB-A $41+$ AMF

口BHICB-A90 + AMF
Figure 3. Effect of inoculation procedure of Anadenanthera peregrina (L.) plants, on survival index of intercropped species Myracrodruon urundeuva Engler (Block I), Schinopsis brasiliensis Engler (Block II) and Acacia sp. (Block III), 20 months after transplanting. Each bar is standard error of 30 observations.
Figure 4. Effect of Anadenanthera peregrina $(\mathrm{L})$ plants, inoculated with rhizobia (BHICB) and mycorrhizal fungi (AMF), on height growth $(\mathrm{cm})$ of intercropped species Myracrodruon urundeuva Engler (Block I), Schinopsis brasiliensis Engler (Block II) and Acacia sp. (Block III), 20 months after transplanting. Each bar is standard error of 30 observations.

ulation, single or associated to BHICB-A10 favoured the survival of all the species. The intensive growth in the root zone of AMF stabilizes the substrate pore volume, which in turn increases the water-holding capacity of the soil $[2,44]$ enhancing drought tolerance and survival of plants and bacteria $[1,28]$. On the other hand, the A. peregrina growth was modified by the block effects (Tabs. I and II). After 4 and 12 months A. peregrina plants of block II, where $S$. brasiliensis was the intercropping species, grew more than the others, while the plants of block III, mixed with Acacia sp., showed a smaller growth. At the end of the analysed period (20 months) the plants of block I, where M. urundeuva was cultivated together with $A$. peregrina, presented the greatest growth (Tab. II). The results of Table III indicate that soil nutrients such as $\mathrm{P}, \mathrm{Ca}, \mathrm{K}, \mathrm{Mg}$ and carbon, were increased 24 months after transplanting, suggesting that nutrients were released from the litter, specially in block I. When the growth of intercropped plants was analysed (Fig. 4), it was observed that Acacia sp. (block III) presented similar growth to A. peregrina. These results suggest that both A. peregrina and Acacia sp. species can compete equally with each other. Acacia growth was modified by inoculation treatments of A. peregrina. Schinopsis brasiliensis is a slow growing species and consequently their plants exhibited the smallest growth (Fig. 4) which was not modified by the inoculation treatments applied to A. peregrina in block II. Nevertheless, in 
Table III. Chemical properties of soils 4 and 24 months after transplanting.

\begin{tabular}{|c|c|c|c|c|c|c|c|c|}
\hline \multirow[b]{3}{*}{ Block I } & \multirow{3}{*}{$\begin{array}{c}\text { Months } \\
4\end{array}$} & \multirow{3}{*}{$\frac{\mathrm{pH}\left(\mathrm{H}_{2} \mathrm{O}\right)}{4.7}$} & $\mathrm{Al}$ & $\mathrm{Ca}$ & $\mathrm{Mg}$ & $\mathrm{P}$ & $\mathrm{K}$ & \multirow{3}{*}{$\begin{array}{r}\mathrm{C} \\
\% \\
0.49\end{array}$} \\
\hline & & & \multicolumn{3}{|c|}{$\left(\mathrm{cmol} / \mathrm{dm}^{3}\right)$} & \multicolumn{2}{|c|}{$\left(\mathrm{mg} / \mathrm{dm}^{3}\right)$} & \\
\hline & & & 0.64 & 0.26 & 0.08 & 0.41 & 22 & \\
\hline & 24 & 4.8 & 0.56 & 0.6 & 0.07 & 1.9 & 27.7 & 1.10 \\
\hline \multirow[t]{2}{*}{ Block II } & 4 & 4.7 & 0.64 & 0.29 & 0.06 & 1.31 & 19 & 0.57 \\
\hline & 24 & 4.8 & 0.55 & 0.46 & 0.06 & 2.3 & 24 & 0.9 \\
\hline \multirow[t]{2}{*}{ Block III } & 4 & 4.5 & 0.64 & 0.17 & 0.04 & 0.79 & 16 & 0.57 \\
\hline & 24 & 4.7 & 0.54 & 0.32 & 0.04 & 1.8 & 20.2 & 0.90 \\
\hline Undisturbed area of Caatinga & 4 & 6.0 & 0.0 & 3.23 & 0.40 & 2.0 & 115 & 1.69 \\
\hline Soil under Carrasco & 4 & 4.9 & 0.42 & 0.37 & 0.08 & 0.29 & 16 & 0.7 \\
\hline Disturbed area & 4 & 5.3 & 0.21 & 0.38 & 0.05 & 0.13 & 16 & 0.32 \\
\hline
\end{tabular}

Table IV. ANOVA for mass, cellulose and lignin losses of litterbags leaves as affected by species (type of litter) and time (4 and 8 months) after field incubation.

\begin{tabular}{|c|c|c|c|c|c|c|c|}
\hline \multirow{2}{*}{ Sources of variation } & \multirow{2}{*}{ d.f } & \multicolumn{2}{|c|}{ Mass remaining } & \multicolumn{2}{|c|}{ Cellulose remaining } & \multicolumn{2}{|c|}{ Lignin remaining } \\
\hline & & MS & $\mathrm{F}$ & MS & $\mathrm{F}$ & MS & $\mathrm{F}$ \\
\hline Litter types & 4 & 22.08 & 141.34 & 1.52 & 268.5 & 5.65 & 253.6 \\
\hline Time & 2 & 342.27 & 2190.4 & 10.456 & 1843.0 & 0.17 & 7.84 \\
\hline Interaction & 8 & 0.0666 & $41.14^{* * *}$ & 0.26 & $45.55^{* * *}$ & 1.42 & $63.57^{* * *}$ \\
\hline
\end{tabular}

${ }^{*} P<0.05,{ }^{* *} P<0.01,{ }^{* * *} P<0.001$.

Table V. Decay rate and nutrients (nitrogen and phosphorus ) release for each litter type after 8 months of incubation.

\begin{tabular}{|c|c|c|c|c|c|c|}
\hline Treatments & $\begin{array}{l}\text { Mass remain (\%) } \\
4 \text { months }\end{array}$ & $\begin{array}{l}\text { Mass remain (\%) } \\
8 \text { months }\end{array}$ & $\begin{array}{c}\mathrm{K} \\
\left(\text { year }^{-1}\right)\end{array}$ & $\begin{array}{l}\mathrm{N} \text { released } \\
(\mathrm{mg} / \mathrm{g} \text { litter })\end{array}$ & $\begin{array}{l}\text { P released } \\
(\mathrm{mg} / \mathrm{g} \text { litter })\end{array}$ & $\begin{array}{c}\text { Lignin: } \mathrm{N} \\
\text { (initial composition) }\end{array}$ \\
\hline A. peregrina & $57.24^{\mathrm{a}}$ & $48.78^{a}$ & 1.38 & 170 & 13.6 & 5.7 \\
\hline M. urundeuva & $33.3^{\mathrm{c}}$ & $20.06^{\mathrm{b}}$ & 2.85 & 160 & 10.8 & 6.1 \\
\hline S. brasiliensis & $64.7^{\mathrm{a}}$ & $42.13^{\mathrm{a}}$ & 1.16 & 120 & 10.6 & 14.4 \\
\hline A. peregrina + M. urundeuva & $39.01^{b c}$ & $29.6^{\mathrm{b}}$ & 1.91 & 195 & 13.9 & 5.0 \\
\hline A. peregrina $+S$. brasiliensis & $52.18^{\mathrm{ab}}$ & $51.41^{\mathrm{a}}$ & 1.02 & 90 & 9.8 & 8.9 \\
\hline
\end{tabular}

Means with different letters on each column are significantly different as determined by Tuckey multiple-range test at the 5\% confidence level ( $\leq 0.05)$.

block I the growth of $M$. urundeuva was improved by AMF inoculation of A. peregrina plants (Fig. 4) that can be attributed not only to shade tolerance of $M$. urundeuva, but also to the better use of the available nutrient supplied by $A$. peregrina. Literature showed that soil nutrients such as nitrogen, phosphorus and potassium were increased under $P$. glandulosa more than at adjacent inter-spaces which may be a mechanism to facilitate the plant establishment [22]. The soil analysis (Tab. III), shows a low nutrient content not only in the disturbed site, but also in soils covered with carrasco, contrasting with those observed in the undisturbed area. However, an increase of soil nutrients such as $\mathrm{Ca}, \mathrm{P}$ and $\mathrm{C}$ was observed 24 months after transplanting in the study site, specially in block I. This way, inoculation treatment which was able to increase the $\mathrm{N}$ content of $A$. peregrina leaves may have increased the litter production and nutrient input. On the other hand, mycorrhizal hyphae can obtain additional nutrient from soil organic matter through their decomposition ability [21]. Arbuscular mycorrhizal fungi can exist saprotrophically, enhancing decomposition of organic matter and increasing the phosphorus and nitrogen capture from complex organic material, independently of the host plant and soil phosphorus levels. After biotrophic root colonization, arbuscular mycorrhizae $[23,39]$ may increases $P$ uptake from soil organic phosphate. It is known that mycorrhizal extraradical mycelium is about 10 times higher than intraradical mycelium [35] which extend not only the ability to link the organic matter source to plant roots but also to release nutrients. If mycorrhizal fungi can decompose the organic matter more nutrients may be available to the intercropped plants. However, we need to understand the factors responsible for the better growth of mixed species in block I in comparison to the other mixtures. When the decomposition dynamics was analysed it was observed that the amount of mass remaining and the loss of cellulose and lignin was significantly $(P<0.001)$ affected by the time and species (Tab. IV). The mass loss was higher with $M$. urundeuva litter than with other species (Tab. V). The leaf litter of M. urundeuva was decomposed faster than S. brasiliensis and $A$. peregrina as shown by the decay rate $(\mathrm{K})$ which allowed to 

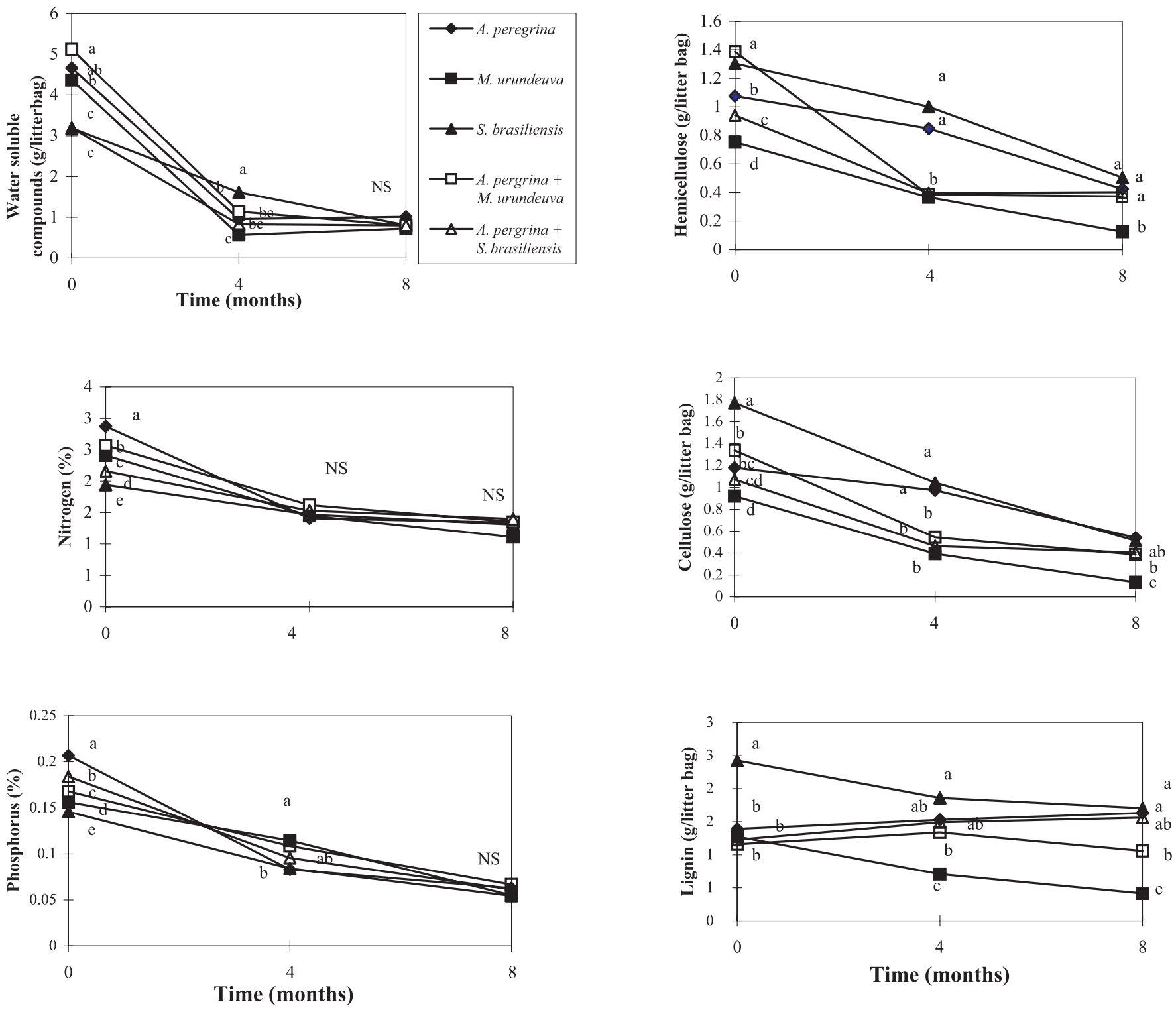

Figure 5. Loss of water soluble compounds, cellulose, hemicellulose, lignin and nutrient release of A. peregrina, Myracrodruon urundeuva and Schinopsis brasiliensis leaves in litterbags, 4 and 8 months after incubation. Means with different letters are significantly different as determined by Tuckey multiple-range test at the 5\% confidence level $(P \leq 0.05)$. NS: not significantly different.

order the annual litter disappearance and nutrient release as: M. urundeuva $>A$. peregrina $+M$. urundeuva $>A$. peregrina $>$ S. brasiliensis $>$ S. brasiliensis + A. peregrina $(\mathrm{Tab}$. V). Literature pointed that decomposition of mixed species can be faster than single-species [32]. Our results showed that this was true only for $A$. peregrina leaves, whose rate of decomposition was improved when mixed with $M$. urundeuva, but the highest values of mass loss were found with $M$. urundeuva and A. peregrina leaves alone. Literature attributes these differences to the quality of decomposition material [29, 32]. In the early phase until the fourth month, concentrations of water soluble substances decrease quickly (Fig. 5). After 8 months cellulose and hemicellulose were degraded whereas the recalcitrant lignin did not decompose. The faster mass loss of $M$. urundeuva may be related to the higher initial concentration of water soluble compounds and the lowest cellulose, hemicellulose and lignin content in leaves (Fig. 5) which may have them become easily decomposed by soil microorganisms [5]. In regard to decomposition rate, an intermediate position was occupied by A. peregrina litter. While the higher initial water soluble compounds, nitrogen, phosphorus concentration and lignin/ $\mathrm{N}$ ratio (Fig. 5 and Tab. V) improved the decomposition rate, the last one was retarded by the increase of cellulose and hemicellulose concentration (Fig. 5). The initial lignin/ $\mathrm{N}$ ratio has been considered as an important factor in controlling the earlier phases of decomposition [17]. Based on the lignin/ $\mathrm{N}$ values of leaf litter in this study (Fig. 5 and Tab. V) we could expect a higher decay index for A. peregrina (Tab. V) but it was lower than M. urundeuva which was 
related to lowest cellulose and hemicellulose concentration of the last one (Fig. 5). The S. brasiliensis litter showed a slow decomposition rate (Fig. 5) for the opposite reason that is a high content of cellulose, hemicellulose and lignin. $\mathrm{N}$ immobilization did not occur in A. peregrina litter (Fig. 5) in agreement with the results obtained in semiarid-soils of West Africa [13]. The results showed in Table $\mathrm{V}$ and Figure 5 suggest that the mixed litter of $A$. peregrina $+M$. urundeuva can favour both $\mathrm{N}$ and $\mathrm{P}$ cycling. Studies in African savannas have shown that $\mathrm{N}$ mineralization is high at the beginning of the wet season, but decrease in dry season [7] and it suggests that the main source of mineralized $\mathrm{N}$ between two wet periods could be dry-season mortality of microbial biomass. Therefore, A. peregrina + M. urundeuva litter may be an additional source of nutrient availability in dry season considering the decomposition ability of mycorrhizal fungi [21]. We can conclude also that biological nitrogen fixation technology associated with mycorrhizal fungi inoculation plays a role in the growth of inoculated plants of semiarid lands $[1,16,20]$. Besides, the AMF inoculation of woody legumes appears to facilitate the establishment of both inoculated legume and uninoculated plants. M. urundeuva was especially promising for inclusion in mixed plantation with $A$. peregrina for restoration programs.

Acknowledgements: This research was supported by Ministry of Environment (MMA)/National Found of Environment (FNMA), Brazilian Council for Research Development (CNPq) and (CODEVASF). Scholarships from CNPq to Maria Rita Scotti and Eduardo Azevedo are kindly acknowledged.

\section{REFERENCES}

[1] Athar M., Johnson D.A., Influence of drought on competition between selected Rhizobium meliloti strains and naturalized soil rhizobia in alfafa, Plant Soil 184 (1996) 231-241.

[2] Augé R.M., Schekel K.A., Wample R.L., Leaf water and carbohydrate status of VA Mycorrhizal rose exposed to drought stress, Plant Soil 99 (1987) 291-302.

[3] Bâ A.M., Plenchette C., Danthu P., Dupponnois R., Guissou T., Functional compatibility of two arbuscular mycorrhizae with thirteen fruit trees in Senegal, Agrofor. Syst. 50 (2000) 95-105.

[4] Beniwal R.S., Toky O.P., Sharma P.K., Effect of V.A. mycorrhizal fungi and phosphorus on growth and nodulation of Acacia nilotica (L.) Willd ex Del., Crop Res. 5 (1992) 172-176.

[5] Berg B., Litter decomposition and organic matter turnover in northern forest soils, For. Ecol. Manage. 133 (2001) 13-22.

[6] Berg B., Ekbohm G., Mcclaugherty C., Lignin and holocellulose relations during long-term decomposition of some forest litters, Can J. Bot. 62 (1984) 2540-2550

[7] Bernhard-Reversat F., Biochemical cycle of nitrogen in a semiarid savanne, Oikos 38 (1982) 321-332.

[8] Biodiversitas, Lista de Espécies ameaçadas de Extinção da Flora do Estado de Minas Gerais, in: Fundação Biodiversitas (Ed.), Belo Horizonte, 1997, pp. 1-47.

[9] Bossuyt H., Denef K., Six J., Frey S.D., Merckx R., Paustian K., Influence of microbial populations and residue quality on aggregate stability, Appl. Soil Ecol. 16 (2001) 195-208.

[10] Callaway R.M., Nadkarni N.M., Mahall B.E., Facilitation and interference of Quercus douglasii on understory productivity in Central California, Ecology 72 (1991) 1484-1499.

[11] Davies F.T., Potter J.R., Linderman R.G., Drought resistance of mycorrhizal pepper plants independent of leaf $\mathrm{P}$ concentration response in gas exchange and water-relations, Physiol. Plant. 87 (1993) $45-53$.
[12] Del Rey, Distrito de Irrigação do Jaíba- Vegetação e manejo de solos Relatório n 5, Belo Horizonte, 1991, p. 77.

[13] Dommergues Y., Garcia J.L., Ganry F., Microbiological considerations of the $\mathrm{N}$-cycle in West African ecosystems, in: Rosswall $\mathrm{T}$. (Ed.), Nitrogen cycling in West African Ecosystems, SCOPE/UNEP Workshop, Idaban, 1980, pp. 55-72.

[14] Embrapa (Empresa Brasilerira de Pesquisa Agropecuária), Manual de Análises Químicas de solos, plantas, e fertilizantes, Brasília, 1979, pp. 1-369.

[15] Founoune H., Duponnois R., Bâ A.M., Bouami F.E., Influence of dual arbuscular endomycorrhizal/ectomycorrhizal symbiosis on the growth of Acacia holosericea (A. Cunn. ex G. Don) in glasshouse conditions, Ann. For. Sci. 59 (2002) 93-98.

[16] Franco-Pizaña J.G., Fulbright T.E., Gardiner D.T., Tipton A.R., Shrub emergence and seedling growth in microenvironments created by Prosopis glandulosa, J. Veg. Sci. 7 (1996) 257-264.

[17] Frankenberg W.T., Abdelmagid H.M., Kinetic parameters of nitrogen mineralization rates of leguminous crops incorporated into soils, Plant Soil 87 (1985) 257-271.

[18] Giovanetti M., Mosse B., An evaluation of techniques for measuring vesicular-arbuscular mycorrhizal infection in roots, New Phytol. 64 (1980) 489-500.

[19] Goering H.K., Van Soest P.J., Forage fiber analysis, in: Agricultural Handbook No. 379, USDA, Washington D.C., 1970, pp. 1-25.

[20] Herrera M.A, Salamanca C.P., Barea J., Inoculation of woody legumes with selected arbuscular Mycorrhizal fungi and rhizobia to recover desertified Mediterranean Ecosystems, Appl. Environ. Microbiol. 59 (1993) 129-133.

[21] Hodge A., Campbell C.D., Fitter AH., An arbuscular mycorrhizal fungus accelerates decomposition and acquires nitrogen directly from organic material, Nature 413 (2001) 297-299.

[22] Johnson H.B., Mayeux H.S., Prosopis glandulosa and the nitrogen balance of rangelands: extent and occurrence of nodulation, Oecologia 84 (1990) 176-185.

[23] Koide R.T., Kabir Z., Extraradical hyphae of the mycorrhizal fungus Glomus intraradices can hydrolyse organic phosphate, New Phytol. 148 (2000) 511-517.

[24] Lal B., Khanna S., Renodulation and nitrogen fixing potential of Acacia nilotica inoculated with Rhizobium isolates, Can. J. Microbiol. 39 (1993) 87-91.

[25] Lal B., Khanna S., Long term field study shows increased biomass production in tree legumes inoculated with Rhizobium, Plant Soil 184 (1997) 111-116.

[26] Manjunath A., Bragyaraj D.J., Gopala Gowada H.S., Dual inoculation with V.A. mycorrhiza and Rhizobium is beneficial to Leucaena, Plant Soil 78 (1984) 445-448.

[27] Marques M.S., Gonçalves L.M.B., Lemos-Filho J.P., Rocha D., Vale M.T.S., Scotti M.R.M., Growth of a leguminous tree (Centrolobium tomentosum Guill. ex Benth) inoculated with Rhizobium and mycorrhizal fungi, Rev. Arg. Microbiol. 29 (1997) 98-102.

[28] Marques M.S., Pagano M., Scotti M.R.M., Dual inoculation of a woody legume (Centrolobium tomentosum) with rhizobia and mycorrhizal fungi in south-easthern Brazil, Agrofor. Syst. 52 (2001) $107-117$.

[29] Marques M.S., Sá N.M.H., Scotti M.R.M., Decomposition, dynamic of inorganic elements and microbial colonization of araribá (Centrolobium tomentosum Guill. ex Benth) leaves on latosols of Brazilian Atlantic forest, Agricult. Tec. 1 (2003) 59-68.

[30] Mazzarino M.J., Oliva L., Abril A., Acosta M., Factors affecting nitrogen dynamics in a semiarid woodland (Dry Chaco, Argentina), Plant Soil 138 (1991) 85-98.

[31] Meetemeyer V., Macroclimate and lignin control of litter decomposition rates, Ecology 59 (1978) 465-472.

[32] Mesquita R.C.G., Workman S.W., Neely C.L., Slow litter decomposition in a Cecropia dominated secondary forest of central Amazonia, Soil Biol. Biochem. 30 (1998) 167-175.

[33] Oliveira S.A., Método simplificado para determinação colorimétrica de nitrogênio em plantas, Ciência e Cultura 38 (1986) 178-180. 
[34] Olson J.S., Energy storage and the balance of producers and decomposers in ecological systems, Ecology 44 (1963) 322-331.

[35] Olsson P.A., Thingstrup I., Jakobsen I., BÅÅth E., Estimation of the biomass of Arbuscular mycorrhizal fungi on a linseed field, Soil Biol. Biochem. 31 (1999) 1879-1887.

[36] Rizzini C.T., Tratado de Fitogeografia do Brasil, Editora da Universidade de São Paulo, São Paulo, 1979, pp. 1-374.

[37] Roldan-Fajardo B.E., Effect of indigenous arbuscular mycorrhizal endophytes on the development of six wild plants colonizing a semiarid area in south-east Spain, New Phytol. 127 (1994) 115-121.

[38] Roskoski I.P., Pepper I., Pardo E., Inoculation of leguminous trees with rhizobia and V.A. Mycorrhizal fungi, For. Ecol. Manage. 16 (1986) 57-68.

[39] Santiago G.M., Garcia Q.S., Scotti M.R.M., Effect of post-planting inoculation with Bradyrhizobium sp. and mycorrizal fungi on the growth of Brazilian rosewood, Dalbergia nigra Allem. ex Benth, in two tropical soils, New For. 24 (2002) 15-24.

[40] Sarruge J.R., Haag H.P., Análises químicas em plantas. Ed. Escola Superior de Agricultura “Luiz de Queiroz”, Piracicaba, 1974, pp. 1-56.

[41] Sharma M.P., Gaur A., Bhatia N.P., Adholeya A., Growth responses and dependence of Acacia nilotica var. cupriciformis on the indige- nous arbuscular mycorrhizal consortium of a marginal wasteland soil, Mycorrhiza 6 (1996) 441-446.

[42] Skjemstad J.O., Janik L.J., Taylor J.A., Non-living soil organic matter: what do we know about it? Aust. J. Exp. Agric. 38 (1998) 667-680.

[43] Somasegaran P., Hoben H.J., Methods in legume-Rhizobium Technology, Ed. Niftal USAID, Hawaii, 1985, pp. 1-367.

[44] Subramanian K.S., Charest C., Dwyer L.M., Hamilton R.I., Effects of arbuscular mycorrhizae on leaf water potential, sugar content, and P content during drought and recovery of maize, Can. J. Bot. 75 (1997) 1582-1591.

[45] Tameirão J.E., Reserva Legal: Avaliação da Cobertura Vegetal, Relatório No. 1, Belo Horizonte, 1997, pp. 1-16.

[46] Taylor B.R., Parkinson D., Parsons W.F.J., Nitrogen and lignin content as predictors of litter decay rates: A microcosm test, Ecology 70 (1989) 97-104.

[47] Udaiyan K., Sugavanam V., Manian S., Growth response of wattle (Acacia mearnsii) seedlings to phosphorus fertilisation and inoculations with Glomus deserticola and Rhizobium sp. in non-sterile soil, J. Trop. For. Sci. 10 (1997) 212-224.

[48] Wesemael B.V., Litter decomposition and nutrient distribution in humus profiles in some mediterranean forests in southern Tuscany, For. Ecol. Manage. 57 (1993) 99-114. 